\title{
ANALISIS PERPUTARAN MODAL KERJA DAN PENGARUHNYA TERHADAP SISA HASIL USAHA (SHU) PADA KOPERASI PEGAWAI NEGERI REPUBLIK INDONESIA (KPNRI) DI KOTA PALU
}

\author{
VANI LESTARI \\ MUH. YUNUS KASIM \\ HUSNAH \\ Jurusan Manajemen, Fakultas Ekonomi, Universitas Tadulako \\ Email: vanilestari90@gmail.com
}

\begin{abstract}
This study proves the influence of working capital turnover (turnover of cash, accounts receivable turnover, inventory turnover) on net income (SHU) at the Civil Servants Cooperative of Republic of Indonesia (KPNRI) in Palu in 2011-2014. The data in this study is time series data in the form of financial statements, which consist of data on the balance sheet and profit/loss or SHU in four consecutive years of 2011-2014 of KPNRI in Palu City. Research sample is 12 cooperatives selected with purposive sampling technique. Model of analysis is multiple linear regressions analysis. The research proves that rotation of working capital includes cash turnover, accounts receivable turnover, inventory turnover simultaneously have significant influence on the SHU with $f$-value of 5.951 and significance level of $0.002<\alpha$ 0.05. Partially, cash turnover positively has significant influence on SHU with t-value of 2.184 with a significant value of $0.034<\alpha 0.05$, receivable turnover has nonsignificant influence on the SHU with $t$-value of 2.595 with significance value of $0.180>\alpha$ of 0.05 , inventory turnover significantly has negative influence on $S H U$ with $t$-value of -2.650 and significance value of $0.004<\alpha 0.05$.
\end{abstract}

Keywords: working capital turnover, turnover of cash, accounts receivable turnover, inventory turnover and time results of operations

\begin{abstract}
Abstrak
Penelitian ini bertujuan untuk membuktikan pengaruh perputaran modal kerja (perputaran kas, perputaran piutang,perputaran persediaan) terhadap sisa hasil usaha (SHU) pada Koperasi Pegawai Negeri Republik Indonesia (KPNRI) di Kota Palu dengan periode penelitian 2011-2014. Data pada penelitian ini adalah data time series berupa laporan keuangan yang terdiri dari data-data pada neraca dan laporan laba/rugi atau SHU selama empat tahun berturut-turut (2011-2014) dari KPNRI Di Kota Palu. Sampel penelitian sebanyak 12 dengan teknik pengambilan sampel menggunakan purposive sampling. Model analisis yang digunakan untuk menjawab hipotesis adalah alat analisis regresi linear berganda. Hasil penelitian membuktikan bahwa secara simultan perputaran modal kerja yaitu perputaran kas, perputaran piutang,perputaran persediaan berpengaruh signifikan terhadap SHU dengan nilai Fhitung sebesar 5.951, dengan tingkat signifikan sebesar $0,002<\alpha 0,05$. Secara parsial perputaran kas berpengaruh signifikan positif terhadap SHU dengan nilai $\mathrm{t}$ hitung sebesar 2.184 dengan nilai signifikansi sebesar $0,034<\alpha 0,05$, perputaran piutang tidak berpengaruh signifikan terhadap SHU dengan nilai t hitung sebesar 2.595 dengan nilai signifikansi sebesar $0,180>\alpha 0,05$, perputaran persediaan berpengaruh signifikan negatif terhadap SHU dengan nilai t hitung sebesar 2,650 dengan nilai signifikansi sebesar $0,004<\alpha 0,05$.
\end{abstract}

Kata Kunci : Perputaran Modal kerja, Perputaran kas, Perputaran piutang, Perputaran persediaan, Sisa Hasil Usaha (SHU)

\section{PENDAHULUAN}

Terdapat beberapa jenis koperasi di Kota Palu, salah satunya adalah Koperasi Pegawai Negeri Republik Indonesia atau disingkat (KPNRI). KPNRI adalah koperasi yang beranggotakan para pegawai negeri di Indonesia. Sama halnya dengan koperasi lain, KPNRI dalam menjalankan kegiatan usahanya perlu memperhatikan dan menjaga kondisi keuangan koperasi dengan baik. Seperti yang dimaksud dalam pasal 4 UU NO. 25 tahun 1992 yaitu membangun dan mengembangkan potensi serta kemampuan ekonomi anggota pada khususnya dan masyarakat pada umumnya, untuk meningkatkan 


\section{Lestari V.}

kesejahteraan ekonomi dan sosialnya. Pengelolaan keuangan koperasi yang baik akan sangat menentukan keberhasilan koperasi dalam mencapai tujuannya. Kondisi kesehatan suatu koperasi dari aspek keuangan ini dapat diketahui dengan melakukan analisis terhadap laporan keuangan koperasi tersebut.

Ada tiga komponen modal kerja yaitu kas, piutang, dan persediaan. Ketiga komponen modal kerja tersebut dapat dikelola dengan cara yang berbeda untuk meningkatkan pertumbuhan perusahaan. Kas merupakan bentuk aktiva yang paling likuid, yang bisa dipergunakan segera untuk memenuhi kewajiban financial perusahaan. Selanjutnya piutang timbul karena adanya penjualan kredit, semakin besar penjulan kredit maka semakin besar pula investasi dalam piutang dan akibatnya risiko atau biaya yang akan dikeluarkan akan semakin besar pula. Komponen modal kerja yang lain dalam penelitian ini adalah persediaan yang merupakan elemen utama dari modal kerja, karena jumlahnya cukup besar dalam suatu perusahaan, jenis persediaan yang ada dalam perusahaan akan tergantung dari jenis perusahaan. Apabila volume penjualan meningkat, maka SHU akan mengalami peningkatan. Akan tetapi pada KPRI karya Bhakti dan KPNRI Beringin yang memiliki peningkatan pada volume pendapatan/penjualan namun kenyataannya sisa hasil usahanya menurun. Hal ini dipengaruhi oleh harga pokok penjualan yang tinggi dan keadaan tersebut menunjukan adanya pengelolaan modal kerja yang kurang baik, dan hal ini dapat mempengaruhi keberhasilan suatu koperasi yang erat kaitanya dengan pencapaian sisa hasil usahanya.

Berdasarkan uraian latar belakang di atas, maka tujuan dalam penelitian ini adalah untuk mengetahui dan menganalisis:

1. Tingkat perputaran modal kerja, perputaran Kas, perputaran Piutang dan perputaran Persediaan pada Koperasi pegawai Negeri Republik Indonesia (KPNRI) di kota Palu?

2. Pengaruh modal kerja terhadap Sisa Hasil Usaha (SHU) pada Koperasi Pegawai Negeri Republik Indonesia (KPNRI) di kota Palu ?

3. Pengaruh tingkat perputaran kas terhadap Sisa Hasil Usaha (SHU) pada Koperasi Pegawai Negeri Republik Indonesia (KPNRI) di kota Palu ?

4. Pengaruh tingkat perputaran piutang terhadap Sisa Hasil Usaha (SHU) pada Koperasi Pegawai Negeri Republik Indonesia (KPNRI) di kota Palu ?

5. Pengaruh tingkat perputaran persediaan terhadap Sisa Hasil Usaha (SHU) pada Koperasi Pegawai Negeri Republik Indonesia (KPNRI) di kota Palu?

\section{KAJIAN LITERATUR DAN PENGEMBANGAN HIPOTESIS Pengertian Koperasi}

Menurut Subandi (2011:18-19), pengertian Koperasi berasal dari bahasa Inggris co-operation, yang berarti usaha bersama. Dengan kata lain berarti segala pekerjaan yang dilakukan bersama-sama sebenarnya dapat disebut sebagai koperasi.

\section{Pengaruh Perputaran Modal KerjaTerhadap Sisa Hasil Usaha}

Modal kerja selalu dibutuhkan oleh setiap badan usaha termaksud koperasi selama kegiatan usahanya semakin berjalan. Kebutuhan modal kerja ini harus terpenuhi dengan jumlah yang cukup agar usaha yang dijalankan dapat berjalan dengan lancar. Maka dengan semakin kecilnya kebutuhan terhadap modal kerja menyebabkan perputaran modal kerja mengalami peningkatan. Sehingga upaya mempercepat perputaran modal kerja ini akan mendukung dalam perolehan sisa hasil usaha. Manajemen modal kerja meliputi : manajemen kas,manajemen piutang, dan manajemen perediaan (Widyati 2011:112).

\section{Kerangka Pemikiran}

Untuk memberikan dasar pemikiran mengenai perputaran modal kerja dan pengaruhnya terhadap sisa hasil usaha, berikut digambarkan kerangka pemikiran penelitian sebagai berikut: 


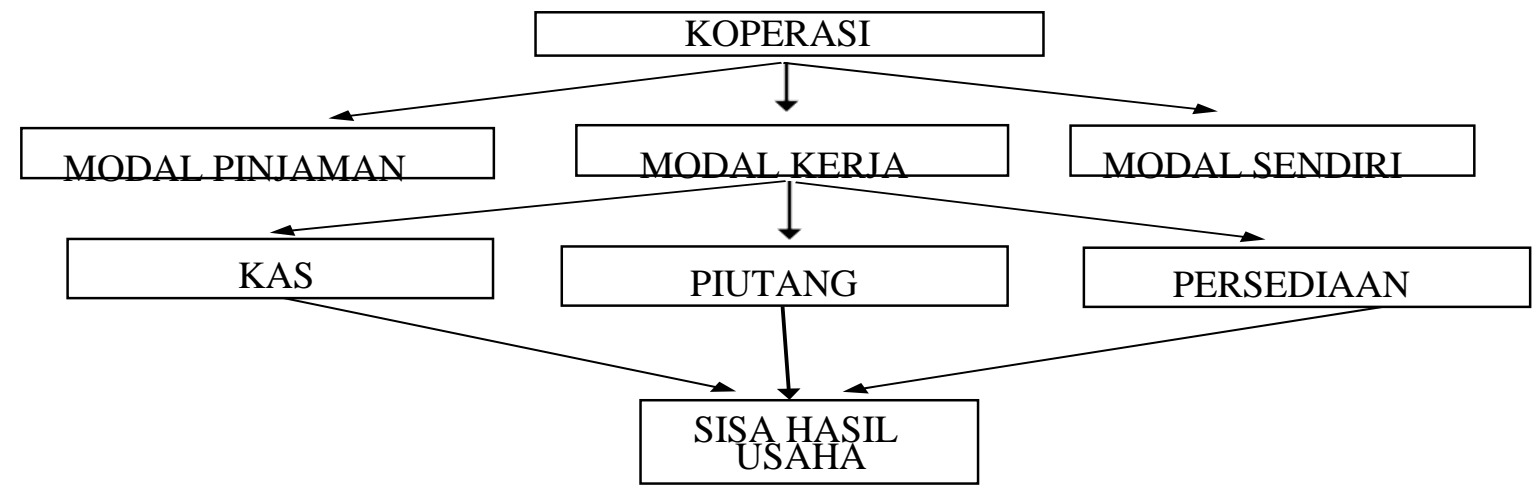

Gambar 1 Kerangka Pemikiran

\section{Hipotesis}

Hipotesis dalam penelitian ini adalah :

1. Perputaran modal kerja yang lebih cepat akan berpengaruh signifikan terhadap sisa hasil usaha pada Koperasi Pegawai Negeri Republik Indonesia (KPNRI) di Kota Palu.

2. Perputaran kas yang lebih cepat akan berpengaruh signifikan terhadap sisa hasil usaha pada Koperasi Pegawai Negeri Republik Indonesia (KPNRI) di Kota Palu.

3. Perputaran piutang yang lebih cepat akan berpengaruh signifikan terhadap sisa hasil usaha pada Koperasi Pegawai Negeri Republik Indonesia (KPNRI) di Kota Palu.

4. Perputaran persediaan yang lebih cepat akan berpengaruh signifikan terhadap sisa hasil usaha pada Koperasi Pegawai Negeri Republik Indonesia (KPNRI) di Kota Palu.

\section{METODE PENELITIAN}

Sesuai dengan jenis data dalam penelitian ini, yaitu data sekunder, maka metode pengumpulan data yang digunakan adalah metode dokumentasi atau disebut juga metode arsip (archival research). Metode Dokumentasi adalah metode pengumpulan data dengan menggunakan konsep-konsep atau teori yang dapat dipakai dalam pembahasan masalah penelitian, meliputi dokumen-dokumen dan jurnal. Metode dokumentasi dalam penelitian ini menggunakan data yang diperoleh dari Dinas PERINDAGKOP yaitu berupa data informasi keuangan Koperasi Pegawai Negeri Republik Indonesia (KPNRI) di Kota Palu pada Periode 2011-2014.

Metode Analisis dalam penelitian ini menggunakan Regresi Linear Berganda. Dalam penelitian ini terdiri dari satu variabel kriterium dan tiga variabel prediktor, sehingga metode analisis data yang digunakan adalah analisis data tiga prediktor.

$$
\mathrm{Y}=\mathrm{a}+\mathrm{b} 1 \mathrm{x} 1+\mathrm{b} 2 \times 2+\mathrm{b} 3 \times 3+\mathrm{e}
$$

Dimana :

$\mathrm{Y}=$ variabel rentabilitas ekonomi

a $=$ konstanta

b1, b2, b3 = koefisien regresi tingkat perputaran kas, piutang dan persediaan

$\mathrm{X} 1$ = tingkat perputaran kas

$\mathrm{X} 2$ = tingkat perputaran piutang $\mathrm{X} 3$

$=$ tingkat perputaran persediaan $\mathrm{e}$

$=$ variabel gangguan

\section{Uji Hipotesis}

\section{Uji Signifikansi Simultan (Uji Statistik F)}

Uji ini digunakan untuk melihat apakah seluruh variabel-variabel independen (x) berpengaruh terhadap variabel dependen(y).

\section{Uji Signifikansi Parsial (Uji-t)}

Untuk menguji kebenaran hipotesis kedua langkah pertama yang dilakukan adalah pengujian secara parsial melalui uji t. 


\section{Lestari V.}

\section{HASIL DAN PEMBAHASAN \\ Analisis data \\ Hasil Regresi Linear Berganda}

Analisis regresi linear berganda digunakan untuk mengetahui bagaimana hubungan antara variabel perputaran kas, perputaran piutang dan perputaran persediaan terhadap sisa hasil usaha dalam hal ini sisa hasil usaha diukur dengan rentabilitas.. Hasil pengolahan data yang telah dilakukan dapat dilihat pada Tabel 8 berikut:

Tabel 1 Hasil Uji Autokorelasi Model Summary

\begin{tabular}{|c|c|c|c|}
\hline \multicolumn{2}{|c|}{ Model } & \multicolumn{2}{c|}{ Unstandardized Coefficients } \\
\cline { 3 - 4 } & (Constant) & B & Std. Error \\
\hline \multirow{2}{*}{} & Perputarn Kas & .038 & 154.387 \\
\cline { 2 - 4 } & Perputaran Piutang & .562 & \\
\cline { 2 - 4 } & Perputaran Persediaan & -.073 & .028 \\
\hline
\end{tabular}

Berdasarkan uraian Tabel 1 di atas tentang hasil perhitungan regresi linear berganda, maka persamaan regresi yang dibangun dengan menggunakan nilai-nilai yang diperlukan sebagai berikut:

$$
\mathrm{Y}=1334,352+.038 \mathrm{X} 1+.562 \mathrm{X} 2-.073 \mathrm{X} 3
$$

\section{Koefisien Determinasi}

Nilai koefisien determinasi antara nol sampai dengan satu. Nilai R2 yang mendekati satu berarti variabel-variabel independen memberikan hampir semua informasi yang dibutuhkan untuk memprediksi variasi variabel dependen.

\section{Uji simultan (Uji F)}

Pengujian hipotesis secara serempak digunakan untuk mengetahui pengaruh antara variabel perputaran kas, perputaran piutang dan perputaran persediaan terhadap sisa hasil usaha pada KPNRI. Untuk lebih jelasnya pengujian hipotesis pertama secara serempak (Uji F) dapat dilihat pada Tabel 2.

Tabel 2 Model Summary

\begin{tabular}{|l|l|c|c|c|c|c|}
\hline \multicolumn{2}{|c|}{ Model } & Sum of Squares & df & Mean Square & F & Sig. \\
\hline \multirow{3}{*}{} & Regression & 8262766.263 & 3 & 2754255.421 & 5.951 & .002 \\
\cline { 2 - 8 } & Residual & 20362811.216 & 44 & 462791.164 & & \\
\cline { 2 - 8 } & Total & 28625577.479 & 47 & & & \\
\hline
\end{tabular}

Berdasarkan Tabel 2 memperlihatkan nilai Fhitung sebesar 5.951, dengan tingkat signifikan sebesar $0,002<\alpha 0,05$. Karena memiliki signifikan lebih kecil dari $\alpha(0.05)$ yaitu sebesar 0.002 menunjukkan bahwa secara serempak perputaran kas, perputaran piutang danperputaran persediaan berpengaruh signifikan terhadap sisa hasil usaha pada Koperasi Pegawai Negeri Republik Indonesia (KPNRI) di Kota Palu. Hal ini berarti hipotesis pertama diterima.

\section{Uji Parsial (Uji t)}

Uji parsial dilakukan dengan statistik t. Hal ini digunakan untuk menguji koefisien regresi secara parsial $(\mathrm{X})$ dari variabel independennya $(\mathrm{Y})$. Berdasarkan hasil pengolahan data yang telah di lakukan, maka hasil dari uji t dapat dilihat pada Tabel berikut:

Tabel 3 Hasil Regresi Uji Parsial (Uji t)

\begin{tabular}{|c|c|c|c|c|c|}
\hline \multirow[t]{2}{*}{ Model } & \multicolumn{2}{|c|}{$\begin{array}{c}\text { Unstandardized } \\
\text { Coefficients }\end{array}$} & \multirow{2}{*}{$\begin{array}{c}\text { Standardized } \\
\text { Coefficients } \\
\text { Beta }\end{array}$} & \multirow[t]{2}{*}{$\mathrm{T}$} & \multirow[t]{2}{*}{ Sig. } \\
\hline & $\mathrm{B}$ & Std. Error & & & \\
\hline (Constant) & 1334.352 & 154.387 & & 8.643 & .000 \\
\hline Perputarn Kas & .038 & .017 & .310 & 2.184 & .034 \\
\hline $\begin{array}{l}\text { Perputaran } \\
\text { Piutang }\end{array}$ & .562 & .216 & .339 & 2.595 & .180 \\
\hline $\begin{array}{l}\text { Perputaran } \\
\text { Persediaan }\end{array}$ & -.073 & .028 & -.378 & -2.607 & .004 \\
\hline
\end{tabular}




\section{Pembahasan Hasil Penelitian \\ Pengaruh Perputaran Modal Kerja Terhadap Sisa Hasil Usaha}

Berdasarkan hasil penelitian ini didapatkan hasil bahwa terdapat pengaruh signifikan antara perputaran modal kerja (perputaran kas, perputaran piutang, dan perputaran persediaan) terhadap sisa hasil usaha (SHU) pada Koperasi Pegawai Negeri Republik Indonesia (KPNRI) di Kota Palu. Pengaruh tersebut sebesar $28,9 \%$, hal ini menunjukan bahwa masih terdapat faktor-faktor lain yang dapat mempengaruhi sisa hasil usaha (SHU). Perputaran modal kerja juga dipengaruhi oleh jumlah pengeluaran kas setiap harinya untuk keperluan pembelian bahan mentah, bahanpembantu, pembayaran upah dan lain-lain. Tingginya tingkat perputaran modal kerja menunjukan banyaknya penjualan yang dapat diperoleh koperasi untuk tiap rupiah modal kerja.

\section{Pengaruh Perputaran Kas Terhadap Sisa Hasil Usaha}

Berdasarkan hasil penelitian ini, menunjukkan bahwa perputaran kas berpengaruh signifikan terhadap rntabilitas atau sisa hasil usaha (SHU) pada Koperasi Pegawai Negeri Republik Indonesia (KPNRI). Dari hasil koefisien regresi perputaran kas memiliki pengaruh positif terhadap rentabilitas yang artinya setiap terjadi peningkatan atau penambahan perputaran kas maka dapat meningkatkan rentabilitas perusahaan. sumber masuknya kas yang telah tertanam dalam modal kerja adalah berasal dari aktivitas operasional perusahaan. Oleh karena itu, sumber kas dalam penelitian ini adalah berasal dari aktivitas penjualan unit pertokoan atau pemberian kredit pada unit simpan pinjam. Idealnya makin tinggi tingkat perputaran kas berarti makin cepat kembalinya uang pada KPRI, kembalinya uang tersebut adalah melalui penjualan pada unit pertokoan serta penerimaan pelunasan kredit pada unit simpan pinjam. Tingkat perputaran kas pada KPNRI di Kota Palu ini terjadi karena adanya penerimaan kas dan volume penjualan tunai yang tinggi. Dari data yang telah dikelola, ada beberapa KPNRI yang nilai perputaran kasnya berada pada kategori sangat tidak efektif yaitu KPNRI Makarti Muktitama yang perputaran kasnya 687\% tahun 2011, 614\% tahun 2012, 448\% tahun 2013 dan 423\% tahun 2014. Kemudian KPNRI Biru yang perputaran kasnya 349\% pada tahun 2011,KPNRI Birawa perputaran kas sebesar 349\% tahun 2011, KPNRI Pengayoman perputaran kas sebesar $436 \%$ tahun 2011 dan 285\% tahun 2012, KPNRI Karya Bhakti yang perputaran kasnya 504\% tahun 2011, 643\% tahun 2012, 800\% tahun 2013, dan 815\% tahun 2014. KPNRI Sejahtera perputaran kas $413 \%$ tahun 2013, 413\% tahun 2014, KPNRI Balkes perputaran kas 555\% tahun 2011, 642\% tahun 2012, 629\% tahun 2013 dan 424\% tahun 2014. Kemudian KPNRI Kuncup mekar perputaran kas 332\% tahun 2011, KPNRI Kartini perputaran kas 306\% tahun 2011, 363\% tahun 2012, 437\% tahun 2013 dan 257\% tahun 2014. KPNRI Ikhlas 131,66\% tahun 2011, 5009\% tahun 2012, 4234\% tahun 2013, dan 477\% tahun 2014. Kemudian KPNRI Simpatik 43.097\% tahun 2011, 2039\% tahun 2012, 1450\% tahun 2013 dan 2099\% tahun 2014. Hal ini terjadi karna meningkatnya penjualan koperasi setiap tahun, sedangkan rata-rata kasnya mengalami penurunan.

\section{Pengaruh Perputaran Piutang Terhadap Sisa Hasil Usaha}

Hasil penelitian ini menyimpulkan bahwa semakin tinggi perputarannya (piutang), yang berarti makin pendek waktu terikat modal dalam piutang sehingga semakin efektif penggunaan modal dalam piutang tersebut. Perputaran piutang yang tinggi dapat meningkatkan rentabilitas karena jumlah piutang tak tertagih semakin sedikit. Perputaran piutang yang tinggi dapat mempengaruhi rentabilitas Koperasi karena jumlah piutang yang dimiliki banyak berarti penjualan kredit yang dilakukan koperasi juga banyak, sehingga volume penjualan juga akan meningkat dan akan menyebabkan rentabilitas perusahaan ikut meningkat.

\section{Pengaruh Perputaran Persediaan Terhadap Sisa Hasil Usaha}

Hasil penelitian menunjukkan bahwa perputaran persediaan berpengaruh signifikan terhadap sisa hasil usaha (SHU) pada Koperasi Pegawai Negeri Republik Indonesia (KPNRI). Namun, berpengaruh secara negative, yang berarti bahwa peningkatan nilai perputaran persediaan akan menurunkan sisa hasil usaha. hal ini terjadi karena perputaran persediaan pada KPNRI di Kota palu sangatlah besar yaitu antara 301\%-16.840\% dan termasuk dalam kategori sangat tidak efektif. Tidak efektifnya nilai perputaran ini disebabkan oleh tingginya nilai penjualan atau pendapatan yang diperoleh dibandingkan dengan rata-rata nilai persediaan. Sehingga nilai perputaran persediaan di semua KPNRI lebih besar di banding nilai rentabilitas koperasinya. 


\section{Lestari V.}

\section{KESIMPULAN DAN SARAN}

\section{Kesimpulan}

Berdasarkan pembahasan diatas dapat disimpulkan sebagai berikut :

1. Berdasarakan analisis, KPNRI di Kota Palu selama tahun 2011-2014 yang memiliki rata-rata perputaran modal kerja yang sangat tidak efekif atau terendah adalah KPNRI Kuncup Mekar yaitu sebesar 0,12 kali atau 12\%, Sedangkan, KPNRI di Kota Palu selama tahun 2011-2014 yang memiliki rata-rata perputaran modal kerja efektif atau tertinggi adalah KPNRI Karya Bhakti yaitu sebesar 1,00 atau $100 \%$.

2. Berdasarakan analisis, KPNRI di Kota Palu selama tahun 2011-2014 yang memiliki rata-rata perputaran kas yang sangat tidak efekif atau terendah adalah KPNRI Simpatikr yaitu sebesar 121,71 kali atau $12.171 \%$, Sedangkan , KPNRI di Kota Palu selama tahun 2011-2014 yang memiliki rata-rata perputran kas efektif atau tertinggi adalah KPNRI Beringin yaitu sebesar 1,60 atau $160 \%$.

3. Berdasarakan analisis, KPNRI di Kota Palu selama tahun 2011-2014 yang memiliki rata-rata perputaran piutang yang sangat tidak efekif atau terendah adalah KPNRI Kuncup Mekar yaitu sebesar 0,13 kali atau 13\%, Sedangkan , KPNRI di Kota Palu selama tahun 2011-2014 yang memiliki rata-rata perputaran piutang tertinggi namun sangat tidak efektif adalah KPNRI Beringinyaitu sebesar 5,87 atau 587\%.

4. Berdasarakan analisis, KPNRI di Kota Palu selama tahun 2011-2014 yang memiliki rata-rata perputaran persediaan yang terendah atau tidak efektif adalah KPNRI Biru yaitu sebesar 4,14kali atau 414\%, Sedangkan, KPNRI di Kota Palu selama tahun 2011-2014 yang memiliki rata-rata perputaran piutang tertinggi namun sangat tidak efektif adalah KPNRI Simpatik yaitu sebesar 113,53 atau $11.353 \%$.

5. Hasil analisis data dengan menggunakan analisa regresi linear berganda menunjukan bahwa perputaran modal berpengaruh signifikan tehadap sisa hasil usaha (SHU), dengan menggunakan salah satu rasio yaiturentabilitas ekonomi.

6. Hasil analisis data menunjukan bahwa perputaran kas berpengaruh signifikan tehadap sisa hasil usaha (SHU), dengan menggunakan salah satu rasio yaitu rentabilitas ekonomi.

7. Hasil analisis data menunjukan bahwa perputaran piutang tidak berpengaruh signifikan tehadap sisa hasil usaha (SHU), dengan menggunakan salah satu rasio yaitu rentabilitas ekonomi.

8. Hasil analisis data menunjukan bahwa perputaran persedian berpengaruh signifikan tehadap sisa hasil usaha (SHU), dengan menggunakan salah satu rasio yaitu rentabilitas ekonomi.

\section{Saran}

Berdasarkan hasil penelitian yang dilakukan, penulis akan memberikan saran sebagai berikut:

a. Kepada tiap-tiap pimpinan KPNRI agar dapat memberikan managemen yang baik bagi koperasinya. Para manager keuangan KPNRI harus menetukan dan menghitung terebih dahuku besar kebutuhan modal kerja yang akan datang agar tidak terjadi kelebihan ataupun kekurangan modal kerja, shingga pembagian dalam tiap elemen modal kerja dapat sngat efektif, Dan tentunya harus berdasarkan pedoman Kementrian Negara Koperasi dan Usaha Kecil Menengah Republik Indonesia

b. Untuk KPNRI yang nilai peputarannya berada pada kategori kurang efektif atau sangat tidak efektif, agar memperpendek syarat pembayaran bagi penjualan kreditnya sehingga modal kerj ayang terikat dalam piutang tidak terlalu lama.

c. Untuk meningkatkan rentabilitas ekonomi pada KPNRI di Kota Palu dapat dilakukan dengan cara lebih mengoptilmkan jumlah aktiva dan memanfaatkannya secara produktif dan efisien agar dapat menghasilkan laba yang optimal pula.

\section{REFERENSI}

Alexandri, Moh Benny. 2012. Managemen Keuangan Bisnis Teori Dan Soal. Bandung: ALFABETA

Subandi (2011). Teknik dan Praktik Koperasi. Bandung: ALFABETA.

Widiyati, N. 2011. Managemen Koperasi. Jakarta: Rincka Cipta. 